\title{
PEDAGOGICAL GRAMMAR AS THE FRAMEWORK OF TEFL RESEARCH. PART 9. THE ROLE OF CONSCIOUSNESS IN THE FOREIGN LANGUAGE ACQUISITION
}

\section{Chernovaty L.M., Doctor of Sciences (Kharkiv)}

The relevance of the paper is accounted for by the need of establishing a common framework to integrate the research in teaching foreign languages, specifically in the development of grammar competence, into a single area with uniform approaches, terminology, and criteria. Its aim is to look for the ways of promoting the efficiency of grammar subskills development by taking into consideration its key features, specifically, the role of consciousness in this process. Basing on the analysis of the native (NLA) and foreign (FLA) language acquisition, the author concludes that one of the main distinctions between the two processes is the degree of actual language awareness on the part of the learners. In the NLA, this process takes place predominantly at the subconscious level (without any actual awareness of the learned material structure and the actions required to use it in communication) with the parallel development of the learners' thinking. In the FLA, under the conditions of formal learning in the classroom, the probability of the said actual awareness on the part of the learners, due to their higher intellectual development, substantially increases, even disregarding the teaching approach. It does affect the acquisition strategies. In the NLA, children are believed to regard speech as a form of behaviour trying to acquire it through assimilation, accommodation, and adaptation to the rules of this activity. In the FLA, in formal settings, learners are believed to regard it as an intellectual task, trying to reach the aim by appropriate solution methods, i.e. by grasping the structure of the activity, looking for the rules it is based on. The difference between these approaches gives grounds to the learning models based on the opposition of acquisition and learning. According to these models, acquisition is an implicit process, essentially identical to the NLA, generally void of any forms of the target language structure awareness, while learning is an explicit process involving some kind of awareness of the target language rules. The analysis of the available data on the comparative efficiency of acquisition and learning in teaching the foreign language proved their inconsistency and led to the conclusion concerning the need for further study of the problem, which constitutes the prospect of further research.

Key words: acquisition, consciousness, foreign language, learning, teaching.

Черноватий Л.М. Педагогічна граматика як фреймове поняття для досліджень у галузі методики навчання іноземних мов. Частина 9. Роль свідомості у засвоснні іноземної мови. Актуальність даного дослідження пояснюється необхідністю пошуку шляхів підвищення ефективності процесу

(C) Chernovaty L.M., 2020 
формування іншомовних граматичних навичок 3 урахуванням закономірностей цього процесу, а його метою $є$ встановлення ролі свідомості в ньому. Виходячи з аналізу процесів засвоєння рідної (РM) та іноземної (IM) мов, автор доходить висновку, що однією 3 ключових їхніх відмінностей $€$ ступінь участі актуального усвідомлення засвоюваного матеріалу індивідом. Якщо при засвоєнні РМ формування граматичних механізмів мови відбувається переважно на підсвідомому рівні (без актуального усвідомлення структури засвоюваного матеріалу та дій 3 його вживання) i паралельно з формуванням мислення, то у випадку оволодіння IM в умовах формального навчання в класі ймовірність такого усвідомлення, з огляду на фактор більш високого рівня інтелектуального розвитку учнів, багаторазово зростає, навіть незалежно від методу навчання. Це впливає на стратегії засвоєння. У випадку РМ діти розглядають мову як форму поведінки і намагаються оволодіти нею за допомогою механізмів асиміляції і акомодації, прагнучи пристосуватися до правил виконання мовленнєвої діяльності. У випадку ж оволодіння IM в умовах формального навчання в класі, учні можуть розглядати цей процес як інтелектуальне завдання, намагаючись упоратися 3 ним методами вирішення таких завдань, тобто прагнучи зрозуміти структуру цієї діяльності та здійснюючи пошук правил іiі реалізації. Різниця в цих підходах до навчання дає підставу розрізняти два різних процеси в оволодінні IM: «засвоєння» (імпліцитне, за своїм змістом ідентичне процесу оволодіння РМ, переважно без усвідомлення структури засвоюваної діяльності) і «учіння» (експліцитне, із залученням актуального усвідомлення правил, властивих відповідній мові). Аналіз досліджень порівняльної ефективності «засвоєння» й «учіння» дозволив зробити висновок про суперечливість їх результатів і необхідність додаткового вивчення даної проблеми, в чому i полягає перспектива подальших досліджень.

Ключові слова: засвоєння, іноземна мова, навчання, свідомість, учіння.

Черноватый Л.Н. Педагогическая грамматика как фреймовое понятие для исследований в области методики обучения иностранным языкам. Часть 9. Роль сознания в усвоении иностранного языка. Актуальность данного исследования объясняется необходимостью поиска путей повышения эффективности процесса формирования иноязычных грамматических навыков с учетом закономерностей этого процесса, а его цель - установление роли сознания в нем. Исходя из анализа процессов усвоения родного (РЯ) и иностранного (ИЯ) языков, автор приходит к выводу, что одним из ключевых их отличий является степень участия актуального осознания усваиваемого материала индивидом. Если при усвоении РЯ формирование грамматических механизмов речи происходит преимущественно на подсознательном уровне (без актуального осознания структуры усваиваемого материала и действий по его употреблению) и параллельно с формированием мышления, то в случае овладения ИЯ в условиях формального обучения в классе вероятность такого осознания, ввиду более высокого уровня интеллектуального развития учащихся, многократно возрастает, даже независимо от метода обучения. Это влияет 
на стратегии усвоения. В случае РЯ дети рассматривают речь как форму поведения и пытаются овладеть ею с помощью механизмов ассимиляции и аккомодации, стремясь приспособиться к правилам выполнения речевой деятельности. В случае же овладения ИЯ в условиях формального обучения в классе, учащиеся могут рассматривать этот процесс как интеллектуальную задачу, пытаясь справиться с ней методами решения таких задач, т.е. стремясь понять структуру этой деятельности и осуществляя поиск правил ее реализации. Разница в этих подходах к обучению дает основание различать два процесса в овладении ИЯ: «усвоение» (имплицитное, по своему содержанию идентичное процессу овладения РЯ, преимущественно без осознания структуры овладеваемой деятельности) и «научение» (эксплицитное, с привлечением актуального осознания правил, присущих соответствующему языку). Анализ исследований сравнительной эффективности «усвоения» и «научения» позволил сделать вывод о противоречивости их результатов и необходимости дополнительного изучения данной проблемы, в чем и заключается перспектива дальнейших исследований.

Ключевые слова: иностранный язык, научение, обучение, сознание, усвоение.

Problem statement. Introduction to the series. Numerous research in teaching foreign languages, specifically in the development of grammar competence, often seem to lack a common framework to integrate them into a single area with uniform approaches, terminology, and criteria. It accounts for the current importance of the issue under consideration.

The aim. The object of this part of the series is the comparative aspect of the native (NLA) and foreign languages acquisition (FLA) with the subject being the characteristics of the FLA, specifically the role of consciousness in this process. Its aim is to analyse the latter with the purpose of its further accounting for in the development of academic programs and actual teaching. This is the ninth (see the previous issues of this journal starting with N 29) in a series of articles focusing on the Pedagogical Grammar (PG) issue [4], where the author, basing on the research data, is planning to discuss the various aspects of the problem.

As it was mentioned in the previous papers of the series (see the note above), the development of an effective PG should be based on a sound psycholinguistic theory of the FLA. This kind of PG has to take into consideration the specifics of the speech grammar mechanisms development in general and the foreign language grammar mechanisms in particular, especially in the spheres where the NLA and FLA features 
are different. In this paper, we are going to review the state of the art in the realm of the role of consciousness in the FLA [30] with a special emphasis on its grammar.

Analysis of current research. Lately, there have been a number of contradictory research related to the problem $[10 ; 11 ; 13 ; 21 ; 24]$, which have been mainly focused on the appropriateness of consciousness raising in the process of FLA or, in other words, on the dichotomy 'implicit (II) vs explicit' instruction (EI). The study of effects of EI and II on the FL learners' acquisition of verb-noun collocations [24] showed that both approaches had a positive effect on establishing initial form-meaning relationships, but II learners outperformed the EI ones in acquisition and retention, as well as in a deeper understanding of the material. In the research on the role of EI and input flood in the acquisition of Spanish discourse markers [13], it was established that the combined effect of EI and II was not superior to II alone. However, other research demonstrated the advantage of EI. The study of uptake in EI of formulaic language in advanced adult FL classes [11] revealed that EI resulted in more uptake as compared to II. Similarly, the study of the grammatical meaning in the second language classroom [21] disclosed that teaching and learning can be enhanced by focusing on the relationship between grammatical forms and their meanings, as elucidated by contemporary linguistic theory [21: 147]. These findings are corroborated by the study of the learners' perceptions of grammar [10], which concluded that students value EI, want teachers to give detailed explanations on grammar, seeking a greater understanding of grammatical structures to comprehend their usage in context [10]. Thus, the problem under consideration requires further research.

Presentation of the main material. As it follows from the analysis of the native language acquisition (NLA) (see the previous issues of this journal starting with $\mathrm{N} 29$ ), this process takes place predominantly at the subconscious level and is based on the child's active interaction with the speech environment. The input information proceeds from the latter into the child's mind where it is processed by a hypothetical device, a 'cognitive organizer' (CO) [15], which is viewed as a component of the child's inherent information processing system that is essentially responsible for the NLA. It is assumed that the CO, basing on the available linguistic input, identifies the underlying principles of the latter, and stores its assumptions (preliminary rules) in the 
corresponding brain area. Analysing the continuous flow of the input, the $\mathrm{CO}$ keeps fine-tuning the system of inner rules (intuitive grammar), gradually transforming it into an adult grammar system. The children are generally unaware of their speech mechanisms as the development of their thinking is at its initial stages, fundamentally depending on the language acquisition because the two processes are closely intertwined.

The situation in the FLA is quite different. In typical cases, children start learning a foreign language (FL) at the age of seven with a limited exposure (one class a week). By this point, the children possess relatively well-acquired competences in their native language (NL) and thinking. The development of abstract thinking is generally over by the age of eleven, and from that time on, the children should be regarded as adults in their learning approaches. There is a considerable difference between the two categories in their acquisition strategies concerning a specific type of activity. Children are believed to regard any activity as a form of behaviour trying to acquire it through assimilation, accommodation, and adaptation to its rules. Adults, on the other hand, are assumed to regard it as an intellectual task, trying to reach the aim by appropriate solution methods, i.e. by grasping the structure of the activity, looking for the rules it is based on $[23 ; 26]$.

The difference between these approaches gave grounds to the models based on the opposition of acquisition and learning [14]. According to its supporters [15], acquisition is essentially identical to the NLA process and can only take place as a result of natural communication where the focus is on its content and not on linguistic forms. Thus, explicit grammar rules and error correction are not relevant for this approach. In addition, it is built on the assumption that there is a well-established 'natural' sequence of the FL structures acquisition. Based upon these suppositions, the awareness of grammar rules was concluded to be inappropriate in the FL acquisition process. Equally unsuitable is believed to be error correction, which should be presumably done by learners themselves on the basis of the so-called 'feel' for grammaticality [15: 2]. In the view of the proponents of this model, acquisition is the result of the CO's processing of the language input from the speech environment (see above).

Unlike acquisition, learning within this approach is supposed [15: 2] to be based on the conscious mastery of the FL on the basis of explicit grammar rules and error correction on the part of the teacher. It is believed that such correction contributes to the development in the 
learner's mind of a specific system properly representing the actual FL system. However, according to the said proponents [14], at present, it is not clear whether such feedback provides for this system's development at all. They believe that one of the reasons for this ambiguity may be the extreme complexity of the actual FL system.

The FL teaching based on learning does not operate any notion of the universal sequence in the FL acquisition (and hence the sequence of the FL items teaching). The latter is usually based on the general didactic principle of accessibility (from the simple to the complex, from the known to the unknown, etc.) [9: 27].

According to the protagonists of the dichotomy under consideration, acquisition and learning are two essentially distinct processes whose outcomes only seem to be identical. The acquired language material is processed in the same way as in the NLA and it is stored in the same areas of the brain. The learned language material may have a metalinguistic character and is not necessarily stored in the same brain areas as the acquired one. That is why the functioning of the former may differ from that of the latter. The acquired language material provides for the natural communication while the learned one may be tapped only through the manipulations on the basis of conscious operations.

Within this model, acquisition is considered the principal engine of mastering the FL. It is believed to be independent of learning and occurs only under appropriate conditions $[15 ; 28]$. According to the advocates of the said hypothesis, the declarative knowledge (concerning the FL structures) appropriated on the basis of learning never transforms into the procedural acquired knowledge, i.e. it does not have any impact on the individual's spontaneous speech. The idea that declarative knowledge gained through learning may be, by means of exercises, integrated into the individual's speech mechanisms alongside the procedural acquired knowledge, is labelled as a 'widespread misconception' [14: 83-84]. To support their theory, the adherents of the acquisition- learning model offer three kinds of evidence: 1) a great number of cases where the FL was mastered exclusively through acquisition without any participation of learning; 2) a great number of cases where learning never turned into acquisition, i.e. where the knowledge of the rules did not affect the learners' communicative competence (see experiments in [17;27]; 3 ) an extreme complexity of the language rules as the objects 
of conscious learning (see the review in [8: 230]). Within this model, the cases when the acquisition of a specific grammar structure had been preceded by conscious memorization of the corresponding grammar rule are interpreted as two (acquisition and learning) separate independent and parallel processes.

The positive correlation between the conscious learning, on the one hand, and the command of the FL, on the other (see, e.g. $[10 ; 11 ; 19$; $20 ; 32]$, is assumed to be explained by the fact that a classroom is capable of providing (especially for the beginners) favourable conditions for the acquisition. The supporters of the acquisitionlearning model presume that the natural speech environment (i.e. the language contained in it) may turn too complicated for the learner, while the simplified language, typically used in the classroom, may be effectively processed by the $\mathrm{CO}$ to develop the FL speech mechanisms [14].

However, according to the opponents [7] of the model under consideration, this assumption is not convincing as it was suggested on the basis of the research on subjects learning the FL through the (varying degree of) conscious approach. It puts the supporters of the acquisition - learning hypothesis into an awkward position, as they have to prove that it is the effect of the $\mathrm{CO}$ subconscious operation and not the consciousness participation that the subjects' progress in command of the language is related to [8]. The works by the proponents of the acquisition-learning model (see [14; 15; 17], for example) do not mention any experiments concerning the comparative efficiency of the conscious and subconscious approaches (but see the research on the role of explicit vs implicit instruction in $[13 ; 18 ; 24])$. However, according to the critics of the said model [8], this is the only way to get a better insight into its relevance. The facts, which are at variance with the acquisition-learning hypothesis fall into several categories. First, it contradicts the experimental data on teaching younger children - contrary to its predictions, the conscious approach in teaching this group of learners is as effective as in the case of adults. Second, advanced learners produced better results with the consciousness-raising techniques. Third, the subjects' performance in different types of tests did not corroborate the said hypothesis either. Contrary to its predictions, the conscious approach improved their performance both in discrete tests (which, according to the hypothesis, measure the effect of learning) and in integrative ones (presumably 
measuring the effect of acquisition) (see the review in [8: 232-234] and the research results in $[10 ; 11 ; 19 ; 20 ; 32]$ for details).

Actually, there are several modifications of the acquisition-learning hypothesis. Its extreme form, formulated by S. Krashen [14-17] and analysed above, disallows the integration of declarative knowledge obtained through learning into the speech mechanisms established through acquisition. Other authors, in varying degrees, assume some kind of integration of the two ways of mastering an FL. Some of them distinguish linguistic and pedagogical rules [27], presumably referring the former to the level of linguistic grammar and the latter - to that of the pedagogical one. The supporters of this approach assume that that the pedagogical grammar rules may contribute to the development of speech skills in two ways - by facilitating the interiorization of the rules, and by duplicating the subconscious speech mechanisms when they are still unstable, creating a kind of backup system [27]. A similar stance is taken up by some other authors [1], which distinguish descriptive and prescriptive rules. In their opinion, only the latter can establish a reliable connection between the descriptive knowledge of the rule and the skill of its automatic use in the natural communication. Unlike the previous author [27], in this case, the mastering of any activity (including speech) on the basis of the learning-acquisition sequence is viewed not only as a possible one but as the most efficient way of teaching. The transformation of declarative knowledge assimilated through learning into the subconscious speech mechanisms built up as a result of acquisition, or in other terms, the combination of explicit and implicit approaches is assumed by a number of other authors as well $[5 ; 13 ; 19 ; 29]$. They argue that it is the classroom learners' capability to use the combined effect of acquisition and learning that gives them an advantage over those that acquire the language in the language environment without any formal learning. Some researchers [5] have suggested substituting the acquisition-learning opposition with the theory of four types of knowledge, which are not opposed to each other but are situated along the common continuum. The extreme left and right positions on the continuum are then occupied by acquisition and learning in S. Krashen's interpretation, while the interim types are characterised by varying degrees of their correlation. Actually, assuming the potentially unlimited amount of variants of such correlation, there is no reason to limit this theory to four types only. The proponents of this model 
attempt assuming the ways in which the said types may transform into others, explaining the higher efficiency of the formal teaching by a greater variety of the aforementioned types students encounter in the classroom (see the review in [8: 237-241]). The possibility of transition from explicit knowledge to automatized operations is also postulated in psychological [2] and language teaching [3] research. The acquisitionlearning model is actually reducible to the subconscious-conscious opposition, the terminology that the authors return to in their other works [6]. Some researchers [12] regard such oppositions as unscientific because they cannot be checked empirically. Others [2; 29] are skeptical about the idea of acquisition and learning being two distinct processes and the impossibility of the learned material to be integrated into the acquired mechanisms and used in spontaneous communication. This idea is certainly the most disputable one, as a great amount of research (see the review in our next papers in the series) in the framework of the mental actions stage development theory [1] have demonstrated the efficiency of grammar actions formation proceeding from the awareness of both the structure of the grammar items and the sequence of operations constituting the grammar actions.

Some other authors have doubted the relevance of the acquisitionlearning opposition and criticized the idea of the overwhelming advantage of acquisition. This criticism ranges from the total rejection of the acquisition-learning opposition validity [2; 29] to the detailed analysis of the model indicating its limitations. The idea of the unquestionable advantage of acquisition over learning turned out to be the most tempting target. Many authors believe that any specially organised teaching is based on the idea of its advantage over any spontaneous process governed by the trial-and-error principle (see [22], for example). Taking into account the notorious lack of time for teaching/learning foreign languages under typical circumstances in standard educational establishments, the admission of the advantage of spontaneous acquisition over specially organised learning would be an admission of the utter futility of learning an FL at school (both a secondary and higher ones, without taking into account the university foreign languages departments and some specialised secondary schools with a special focus on FLs). The total amount of contact hours at these levels runs into hundreds of hours allocated over a substantial time span - over ten years. The inadequacy of the acquisition-learning 
opposition is also corroborated by a number of experimental research (see the review in our next papers in the series). In short-run courses, adults mastering an FL through learning demonstrate a clear advantage over both adults and children relying exclusively on the acquisition approach. However, in the long-run courses, children may eventually catch up and even overtake learning-oriented adults. On the other hand, in analysing that kind of data, there emerges a problem we have mentioned before: it is impossible to distinguish whether the specific structure has been assimilated through acquisition or learning, i.e. the role of consciousness in this process is unclear. The fact that adult students had not been given any explicit rules does not automatically mean that they did not employ their consciousness for the independent analysis of the FL structure. The adults' powerful intellects are undoubtedly capable of applying the conscious analysis though its procedure is subject to considerable individual variations.

Advocating the higher efficiency of learning as compared to acquisition, the respective authors, among their other arguments, mention the views of many experts in language teaching, ranging from M. Berlitz to W. Rivers, as well as to those of the leading psychologists, including L. Vygotsky and others (see [22: 97] for details). They even refer to $\mathrm{H}$. Palmer, the famous founder of the socalled 'Direct Method', which is believed to be based on the principles identical to those of the acquisition approach supporters. H. Palmer cautioned against completely relying on nature in the sphere of language teaching. He believed it would be a fundamental mistake to ignore the powerful intellectual potential, which distinguishes an adult from a child. That is why he stood for the application of techniques (meaning the use of explicit grammar rules), which are efficient, though 'unnatural' [25: 16]. This view was generally shared by some other proponents of the 'Direct Method' and its modifications (see [31], for example).

Conclusions. Basing on the analysis presented above, it may be concluded that there are contrastive views as to the role of consciousness in the process of the FLA. These views may be analysed from the acquisition (implicit learning) vs learning (explicit learning) perspective. The views fall into several approaches, which range from 'explicit only' to 'implicit only' models with other attitudes advocating the use of elements from both methods with a varying degree of their ratio. For justice's sake, it should be mentioned that 
the authors' views are subject to substantial fluctuations. Even S. Krashen in one of his works states that 'promising students' skillfully combine acquisition and learning, keep studying the grammatical structure of the target language, even being in the natural speech environment and effectively use their monitors, i.e. their conscious control over the generation of their speech [15: 37].

Prospects of further research. Thus, this problem requires additional analysis, specifically concerning the role of the monitor in the process of the FL acquisition, which is the prospect of our further research.

\section{LITERATURE}

1. Гальперин П.Я. Основные результаты исследования по проблеме формирования умственных действий и понятий: автореф. дис. на соискание уч. степени д-ра психол. наук: 19.00.01 / Московский государственный университет имени М.В. Ломоносова. Москва, 1965. $39 \mathrm{c}$.

2. Зимняя И.А. Введение в психолингвистику. Москва: Российский государственный гуманитарный университет, 2000. 382 с.

3. Методика навчання іноземних мов та культур: теорія і практика/ Бігич О.Б. та ін.; за ред. С.Ю. Ніколаєвої. Київ: Ленвіт. 2013. 590 с.

4. Черноватый Л.Н. Основы теории педагогической грамматики иностранного языка: дис. ... д-ра пед. наук: 13.00.02 / Харьковский национальный университет им. В.Н. Каразина. Харьков, 1999. 453 с.

5. Bialostock E. On the relationship between knowing and using forms. Applied Linguistics. 1982. Vol. 3. P. 181-206.

6. Dulay H., Burt M., Krashen S. Language Two. New York: Oxford Univ. Press, 1982. $315 \mathrm{p}$.

7. Ellis R. Instructed Second Language Acquisition. Cambridge, Mass.: Blackwell, 1992. $230 \mathrm{p}$.

8. Ellis R. Understanding Second Language Acquisition. London: Oxford Univ. Press, 1989. $327 \mathrm{p}$.

9. Eşi Marius-Costel. The didactic principles and their applications in the didactic activity. Sino-US English Teaching. 2010. Vol. 7. N 9. P. 24-34.

10. Fujino H. L2 learners' perceptions of grammar: the case of JFL learners in the UK. The Language Learning Journal. 2019. Published Online: 01 Mar. 2019. DOI: https://doi.org/10.1080/09571736.2019.1578399.

11. Gholami L., Gholami J. Uptake in incidental focus-on-form episodes concerning formulaic language in advanced adult EFL classes. Language Teaching Research. 2020. Vol. 24, N 2. P. 189-219. DOI: https://doi.org/10.1177/1362168818783442. 
12. Greg K. Krashen's Monitor and Occam's Razor. Applied Linguistics. 1984. № 5. P. 79-100.

13. Hernández T.A. Re-examining the role of explicit instruction and input flood on the acquisition of Spanish discourse markers. Language Teaching Research. 2011. Vol. 15. N 2. P. 159-182. DOI: https://doi.org/10.1177/1362168810388694.

14. Krashen S. Principles and Practice in Second Language Acquisition. Oxford: Pergamon, 1982. 202 p.

15. Krashen S. Second Language Acquisition and Second Language Learning. Cambridge: Prentice-Hall, 1981. 212 p.

16. Krashen S. The comprehension hypothesis and its rivals. Selected Papers from the Eleventh International Symposium on English Teaching. Fourth Pan-Asian Conference. 2002. Taipei: Crane Publishing Company. P. 395-404.

17. Krashen S., Pon P. An error analysis of an advanced ESL learner: the importance of the Monitor. Working Papers on Bilingualism. 1975. Vol. 7. P. 125-129.

18. Leow R.P. ISLA: How implicit or how explicit should it be? Theoretical, empirical, and pedagogical/curricular issues. Language Teaching Research. 2018. Vol. 23. N 4. P. 476-493. DOI: https://doi.org/ $10.1177 / 1362168818776674$

19. Liamkina O., Ryshina-Pankova M. Grammar Dilemma: Teaching Grammar as a Resource for Making Meaning. The Modern Language Journal. 2012. Vol. 96. N 2. P. 270-289. DOI: https://doi.org/10.1111/j.1540781.2012.01333_1.x.

20. Liviero S. Grammar teaching in secondary school foreign language learning in England: teachers' reported beliefs and observed practices. The Language Learning Journal. 2017. Vol. 45. N 1. P. 26-50. DOI: https://doi.org/10.1080/09571736.2016.1263677.

21. Marsden H., Slabakova R. Grammatical meaning and the second language classroom: Introduction. Language Teaching Research. 2017. Vol. 23. N 2. P. 147-157. DOI: https://doi.org/10.1177/1362168817752718/.

22. Marton W. Some remarks on the anti-pedagogical aspects of Krashen's theory of second-language acquisition. Studia Anglica Poznaniensia. 1990. Vol. 23. P. 95-110.

23. McLaughlin B. The Monitor Model: some methodological considerations. Language Learning. 1978. Vol. 28. P. 309-332.

24. Mei-Hsing Tsai. The effects of explicit instruction on L2 learners' acquisition of verb-noun collocations. Language Teaching Research. 2018. Vol. 24. $\quad$ N 2. $\quad$ P. 138-146. $\quad$ DOI: https://doi.org/10.1177/ 1362168818795188.

25. Palmer H. The Principles of Language Study. London: Oxford Univ. Press, 1964. $212 \mathrm{p}$. 
26. Rosansky E. The critical period for the acquisition of language: some cognitive developmental considerations. Working Papers in Bilingualism. 1975. Vol. 6. P. 92-102.

27. Seliger $\mathrm{H}$. On the nature and function of language rules in language teaching. TESOL Quarterly. 1979. Vol. 13. P. 359-369.

28. Seliger H., Krashen S., Ladefoged P. Maturational constraints in the acquisition of a native-like accent in second language learning. Language Sciences. 1975. Vol. 36. P. 20-22.

29. Sharwood Smith M. Notions and Functions in a Contrastive Pedagogical Grammar / eds. W. Rutherford, M. Sharwood Smith. Grammar and Second Language Teaching. Boston: Heinle and Heinle. 1988. P. 156-170.

30. Sharwood Smith, M. Revisiting the role of consciousness with MOGUL / ed. Han Z. Understanding Second Language Processes. Clevedon: Multilingual Matters, 2007. P. 1-15.

31. Strevens P. Teaching English as an International Language: from Practice to Principle. Oxford: Pergamon Press, 1980. 360 p.

32. Umeda M., Snape N., Yusa N., Wiltshier J. The long-term effect of explicit instruction on learners' knowledge on English articles. Language Teaching Research. 2017. Vol. 23. N 2. P. 179-199. DOI: https://doi.org/ $10.1177 / 1362168817739648$.

\section{REFERENCES}

1. Galperin, P.Ja. (1965). Osnovnye rezultaty issledovanija po probleme formirovanija umstvennyh dejstvij i ponjatij [Main Results of the Research into the Development of Mental Actions and Concepts. Extended abstract of Doctor's thesis. Moscow: M.V. Lomonosov Moscow State University [in Russian].

2. Zimnjaja, I.A. (2000). Vvedenie v psiholingvistiku [Introduction into Psycholinguistics]. Moscow: Russian State Humanitarian University [in Russian].

3. Bihych, O.B. et al. (2013). Metodyka navchannia inozemnykh mov ta kultur: teoriia i praktyka [Methodology of Teaching Foreign Languages and Cultures]. Nikolaieva, S.Yu. (Ed.). Kyiv: Lenvit [in Ukrainian].

4. Chernovaty, L. (1999). Osnovy teorii pedagogicheskoi grammatiki inostrannogo yazyka [The Basics of the Foreign Language Pedagogical Grammar Theory]. Doctor's thesis. Kharkiv: V.N. Karazin Kharkiv National University [in Russian].

5. Bialostock, E. (1982). On the relationship between knowing and using forms. Applied Linguistics. Vol. 3, pp. 181-206 [in English].

6. Dulay, H., Burt, M. and Krashen, S. (1982). Language Two. New York: Oxford Univ. Press [in English]. 
7. Ellis, R. (1989). Understanding Second Language Acquisition. London: Oxford Univ. Press [in English].

8. Ellis, R. (1992). Instructed Second Language Acquisition. Cambridge, Mass.: Blackwell [in English].

9. Eşi, Marius-Costel. (2010). The didactic principles and their applications in the didactic activity. Sino-US English Teaching. Vol. 7, N 9, pp. 24-34 [in English].

10. Fujino, H. (2019). L2 learners' perceptions of grammar: the case of JFL learners in the UK. The Language Learning Journal. Published Online: 01 Mar. 2019 [in English]. DOI: https:/doi.org/10.1080/ 09571736.2019.1578399.

11. Gholami, L. and Gholami, J. (2020). Uptake in incidental focus-on-form episodes concerning formulaic language in advanced adult EFL classes. Language Teaching Research. Vol. 24, N 2, pp. 189-219 [in English]. DOI: https:/doi.org/10.1177/1362168818783442.

12. Greg, K. (1984). Krashen's Monitor and Occam's Razor. Applied Linguistics. № 5, pp.79-100 [in English].

13. Hernández, T.A. (2011). Re-examining the role of explicit instruction and input flood on the acquisition of Spanish discourse markers. Language Teaching Research. Vol. 15, N 2, pp. 159-182 [in English]. DOI: https://doi.org/10.1177/1362168810388694.

14. Krashen, S. (1981). Second Language Acquisition and Second Language Learning. Cambridge: Prentice Hall [in English].

15. Krashen, S. (1982). Principles and Practice in Second Language Acquisition. Oxford: Pergamon [in English].

16. Krashen, S. (2002). The comprehension hypothesis and its rivals. Selected Papers from the Eleventh International Symposium on English Teaching. Fourth Pan-Asian Conference. Taipei: Crane Publishing Company, pp. 395-404 [in English].

17. Krashen, S. and Pon, P. (1975). An error analysis of an advanced ESL learner: the importance of the Monitor. Working Papers on Bilingualism. Vol. 7, pp. 125-129 [in English].

18. Leow, R.P. (2018). ISLA: How implicit or how explicit should it be? Theoretical, empirical, and pedagogical/curricular issues. Language Teaching Research. Vol. 23, N 4, pp. 476-493 [in English]. DOI: https://doi.org/10.1177/1362168818776674.

19. Liamkina, O. and Ryshina-Pankova, M. (2012). Grammar Dilemma: Teaching Grammar as a Resource for Making Meaning. The Modern Language Journal. Vol. 96, N 2, pp. 270-289 [in English]. DOI: https://doi.org/10.1111/j.1540-781.2012.01333_1.x.

20. Liviero, S. (2017). Grammar teaching in secondary school foreign language learning in England: teachers' reported beliefs and observed practices. 
The Language Learning Journal. Vol. 45, N 1, pp. 26-50 [in English]. DOI: https://doi.org/10.1080/09571736.2016.1263677.

21. Marsden, H. and Slabakova, R. (2017). Grammatical meaning and the second language classroom: Introduction. Language Teaching Research. Vol. 23, N2, pp. 147-157 [in English]. DOI: https://doi.org/10.1177/1362168817752718.

22. Marton, W. (1990). Some remarks on the anti-pedagogical aspects of Krashen's theory of second-language acquisition. Studia Anglica Poznaniensia. Vol. 23, pp. 95-110 [in English].

23. McLaughlin, B. (1978). The Monitor Model: some methodological considerations. Language Learning. Vol. 28, pp. 309-332 [in English].

24. Mei-Hsing, T. (2018). The effects of explicit instruction on L2 learners' acquisition of verb-noun collocations. Language Teaching Research. Vol. 24, N2, pp. 138-146 [in English]. DOI: https://doi.org/10.1177/1362168818795188.

25. Palmer, H. (1964). The Principles of Language Study. London: Oxford Univ. Press [in English].

26. Rosansky, E. (1975). The critical period for the acquisition of language: some cognitive developmental considerations. Working Papers in Bilingualism. Vol. 6, pp. 92-102 [in English].

27. Seliger, H. (1979). On the nature and function of language rules in language teaching. TESOL Quarterly. Vol.13, pp.359-369 [in English].

28. Seliger, H., Krashen, S. and Ladefoged, P. (1975). Maturational constraints in the acquisition of a native-like accent in second language learning. Language Sciences. Vol. 36, pp. 20-22 [in English].

29. Sharwood Smith, M. (1988). Notions and Functions in a Contrastive Pedagogical Grammar. Rutherford, W. and Sharwood Smith, M. (Eds.). Grammar and Second Language Teaching. Boston: Heinle and Heinle, pp. 156-170 [in English].

30. Sharwood Smith, M. (2007). Revisiting the role of consciousness with MOGUL. Han, Z. (Ed.). Understanding Second Language Processes. Clevedon: Multilingual Matters, pp. 1-15 [in English].

31. Strevens, P. (1980). Teaching English as an International Language: from Practice to Principle. Oxford: Pergamon Press [in English].

32. Umeda, M., Snape, N., Yusa, N. and Wiltshier, J. (2017). The long-term effect of explicit instruction on learners' knowledge on English articles. Language Teaching Research. Vol. 23, N2, pp. 179-199 [in English]. DOI: https://doi.org/10.1177/1362168817739648. 
Черноватий Леонід Миколайович, докт. пед. наук, професор кафедри перекладознавства імені Миколи Лукаша факультету іноземних мов Харківського національного університету імені В.Н. Каразіна (61022, Харків, майдан Свободи, 4); e-mail: leonid.chernovaty@ karazin.ua; orcid: http://orcid.org/0000-0003-3411-9408.

Черноватый Леонид Николаевич, докт. пед. наук, профессор кафедры переводоведения имени Николая Лукаша факультета иностранных языков Харьковского национального университета имени В.Н. Каразина (61022, Харьков, площадь Свободы, 4); e-mail: leonid.chernovaty@karazin.ua; orcid: http://orcid.org/0000-0003-3411-9408. Leonid Chernovaty, Doctor of Pedagogics, Full Professor, The School of Foreign Languages, Mykola Lukash Translation Studies Department, V.N. Karazin Kharkiv National University (61022, Kharkiv, 4 Svoboda Square); e-mail: leonid.chernovaty@karazin.ua; orcid: http://orcid.org/00000003-3411-9408. 